\title{
Reproductive output, foraging destinations, and isotopic niche of olive ridley and loggerhead sea turtles, and their hybrids, in Brazil
}

\author{
Luciano S. Soares ${ }^{1,2, *}$, Karen A. Bjorndal ${ }^{1,2}$, Alan B. Bolten ${ }^{1,2}$, Marta L. Wayne ${ }^{2,3}$, \\ Jaqueline C. Castilhos ${ }^{4}$, Marilda I. Weber ${ }^{4}$, Milagros López-Mendilaharsu ${ }^{5}$, \\ Maria A. Marcovaldi ${ }^{5}$, Sibelle T. Vilaça ${ }^{6}$, Eugenia Naro-Maciel $^{7}$ \\ ${ }^{1}$ Archie Carr Center for Sea Turtle Research, University of Florida, Gainesville, FL 32611, USA \\ ${ }^{2}$ Department of Biology, University of Florida, Gainesville, FL 32611, USA \\ ${ }^{3}$ University of Florida Genetics Institute, University of Florida, Gainesville, FL 32611, USA \\ ${ }^{4}$ Projeto TAMAR/Fundação Pró-TAMAR, Aracaju, SE 49035-730, Brazil \\ ${ }^{5}$ Projeto TAMAR/Fundação Pró-TAMAR, Salvador, BA 41510-045, Brazil \\ ${ }^{6}$ Department of Life Sciences and Biotechnology, University of Ferrara, Ferrara 44121, Italy \\ ${ }^{7}$ Liberal Studies, New York University, New York, NY 10003, USA
}

\begin{abstract}
Hybridization is a fundamental evolutionary and ecological process with significant conservation ramifications. Sea turtle hybridization occurs at unusually high frequencies along the northeastern coast of Brazil. To better understand the process, we studied the reproductive output, migration patterns (through satellite telemetry), and isotopic niches of loggerhead turtles Caretta caretta and olive ridley turtles Lepidochelys olivacea and their hybrids. We classified 154 nesting females as loggerhead $(n=91)$, olive ridley $(n=38)$, or hybrid $(n=25)$ based on mitochondrial and nuclear DNA. Further, we compared nesting female morphological data and reproductive parameters (clutch size, emergence success, hatchling production, incubation period) of 405 nests among hybrids and parental species. We found no significant differences among the 3 groups when hatchling production was corrected for female body size, indicating that hybrids and parental species produce similar numbers of hatchlings per clutch. Satellite tracking of 8 postnesting hybrid females revealed shared foraging grounds with both parental species, as well as neritic migrations between foraging and nesting areas similar to those previously reported for loggerheads and olive ridleys. Analyses of ${ }^{13} \mathrm{C}$ and ${ }^{15} \mathrm{~N}$ isotope values $(\mathrm{n}=69)$ further confirmed this pattern, as hybrid isotopic niches overlapped extensively with both parental species. Thus, given the similarities presented between hybrids and their parental species in reproductive, ecological, and behavioral characteristics, we conclude that these hybrids may persist along with other sea turtle nesting populations in the area, with research and conservation implications.
\end{abstract}

KEY WORDS: Hybridization - Marine turtle $\cdot$ Satellite tracking $\cdot$ Reproductive output $\cdot$ Foraging Migration $\cdot$ Isotopic niche $\cdot$ Mitochondrial and nuclear DNA

\section{INTRODUCTION}

Species boundaries and hybridization are primary research areas in conservation, ecology, and evolutionary biology. Hybridization has been reported in at least $25 \%$ of plant and $10 \%$ of animal species

*Corresponding author: lsoares@ufl.edu
(Mallet 2005) and may result in fitness declines (Arnold \& Hodges 1995) as well as the loss of rarer groups to genetic swamping (Todesco et al. 2016). However, hybridization may also promote hybrid vigor (Rhymer \& Simberloff 1996) or genetic rescue by introducing new alleles (Stronen \& Paquet 2013). 
Hybrids may occupy ecological niches and fulfill roles of one or both parental taxa, either supporting food webs that included depleted parental populations, or outcompeting the parental species (Stronen \& Paquet 2013). Given the varied possible outcomes, there is a clear need for research and monitoring of this process.

Hybridization has been reported among most of the hard-shelled sea turtle species (Cheloniidae), although usually at very low rates within populations (Bowen \& Karl 2007). Most articles that report hybridization have 1 or 2 hybrid individuals or a few hatchlings within a clutch, with the caveat that the low incidence could be an artifact of inappropriate genetic markers used for hybrid identification in previous research (Bowen \& Karl 2007). In Brazil, however, mitochondrial and nuclear DNA studies revealed unusually high rates of sea turtle hybridization at major loggerhead Caretta caretta and hawksbill Eretmochelys imbricata nesting grounds in the northeastern state of Bahia (Lara-Ruiz et al. 2006, Bowen \& Karl 2007, Vilaça et al. 2012). Loggerhead and hawksbill hybrids, for example, remarkably constitute $30-40 \%$ of the nesting population there, potentially representing significant conservation concerns. Relative to their parental species, loggerhead $\times$ hawksbill hybrids had similar reproductive parameters (clutch size, emergence success, incubation period, hatchling production, observed clutch frequency, observed annual production, observed breeding frequency, observed total production; Soares et al. 2017) and exhibited no decreased fitness as expressed by hatchling viability or hybrid breakdown (Soares et al. 2018).

The migratory patterns of sea turtle species and their hybrids have been the subject of recent satellite tracking research. In Brazil, loggerhead turtles were found to forage off the northern coast (Marcovaldi et al. 2010). In contrast, hawksbill feeding areas occur off the northeastern state of Bahia in coral reef ecosystems, while hawksbill $\times$ loggerhead hybrids were found to forage only in the northern areas used by the loggerheads (Marcovaldi et al. 2012). In morphologically assigned olive ridleys, on the other hand, a range of migratory movements were reported, including migrations to the north and south, and to coastal and offshore areas within and outside the Brazilian exclusive economic zone (da Silva et al. 2011, Santos et al. 2019).

Loggerheads and olive ridleys are the most common nesters in the northeastern states of Bahia and Sergipe in Brazil, where they are nevertheless nationally classified as 'in danger,' while being listed as
'Vulnerable' globally by the International Union for the Conservation of Nature (Abreu-Grobois \& Plotkin 2008, Casale \& Tucker 2017). Long-term conservation efforts carried out by Projeto TAMAR/Fundação PróTAMAR have contributed to increasing population trends for both species in these areas (da Silva et al. 2007, Marcovaldi \& Chaloupka 2007). Hybridization between loggerhead and olive ridley turtles in Brazil, estimated at $27 \%$ (Reis et al. 2010), appears to be less frequent than that between loggerheads and hawksbills, but remains insufficiently characterized.

To further our understanding of loggerhead $\times$ olive ridley hybridization, in a multidisciplinary approach we: (1) used morphological and genetic methods to identify loggerheads, olive ridleys, and their hybrids nesting in the states of Sergipe and northern Bahia (Fig. 1); (2) compared body size of nesting females and their reproductive output (clutch size, emergence success, hatchling production per clutch, and incubation period); (3) evaluated migratory patterns and foraging distributions through satellite telemetry; and (4) investigated resource use through isotopic niches based on $\delta^{13} \mathrm{C}$ and $\delta^{15} \mathrm{~N}$. The combination of reproductive biology, genetic analysis, satellite telemetry, and stable isotopes is an effective approach for comparing ecological or behavioral characteristics (e.g. migration, foraging, and resource use) of hybrids and parental species.

\section{MATERIALS AND METHODS}

\subsection{Sampling}

Researchers from the Brazilian Sea Turtle Conservation and Research Program (Projeto TAMAR/Fundação Pró TAMAR and Centro TAMAR /ICMBio) patrolled major nesting beaches in the states of Bahia and Sergipe between September and March from 1988 through 2015. When encountered, nesting females were morphologically assigned to a species by experienced biologists using the TAMAR protocol (based on Pritchard \& Mortimer 1999), but mixed traits that could suggest hybridization were noted.

\subsection{Genetics}

Between 2002 and 2015, during the field work described above, 154 skin samples from morphologically identified loggerhead and olive ridley turtles (see Section 2.3) were collected for genetic analysis by TAMAR personnel. Standard procedures were 

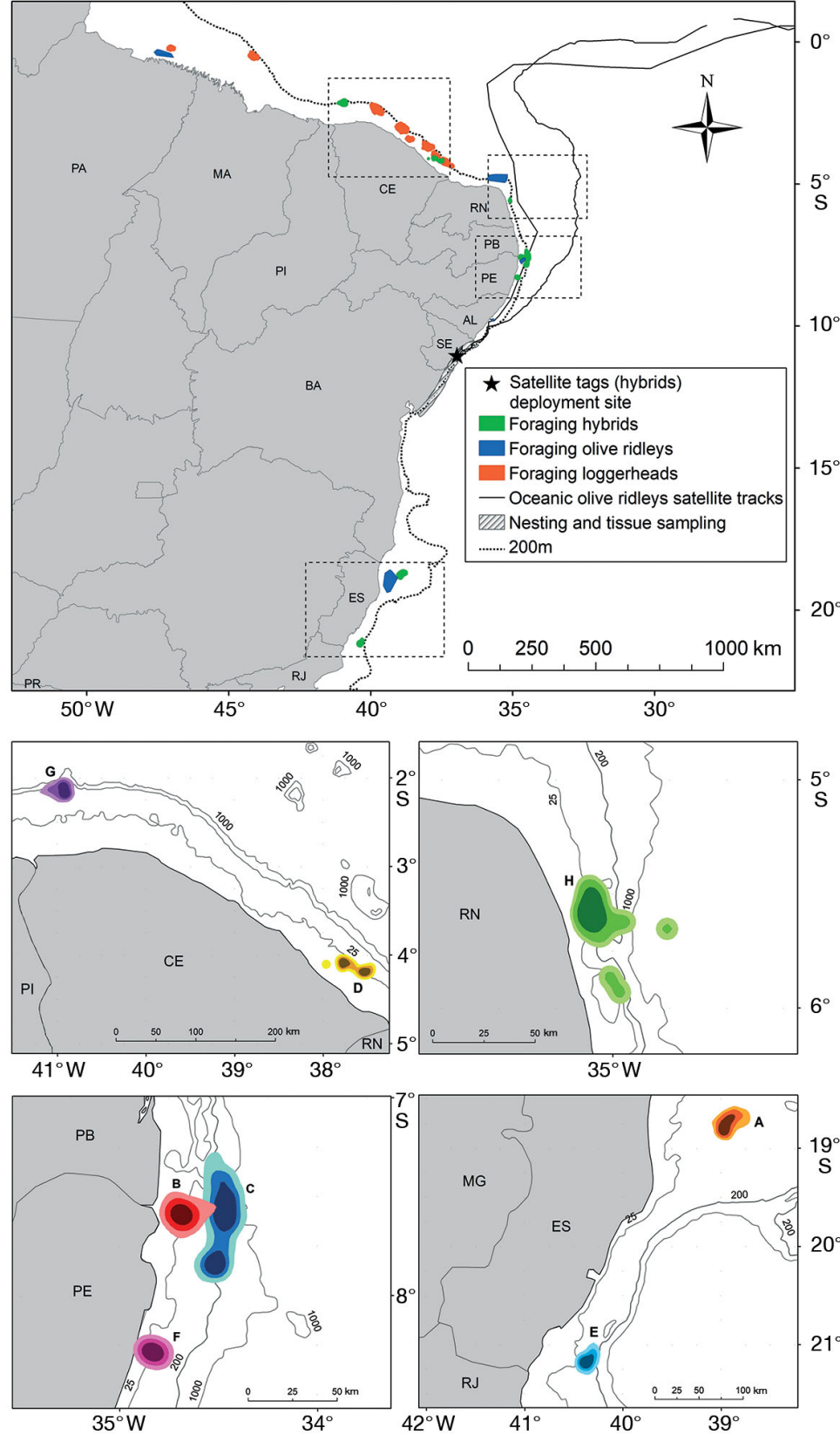

Fig. 1. Nesting, tissue sampling, and satellite deployment sites, as well as foraging areas for hybrids (this study), loggerheads (adapted from Marcovaldi et al. 2012), and olive ridleys (adapted from da Silva et al. 2011). Dashed rectangles highlight the locations of the enlarged maps, from north to south. Enlarged maps show individual foraging areas of hybrids with 50, 75, and $90 \%$ kernel home range estimates from darker to lighter patterns. Capital letters inside enlarged maps are individual turtle IDs

followed, and samples were obtained from between the first and second scales on the front flippers or the neck region of nesting turtles. Disposable biopsy punches were used, and samples were stored in $70 \%$ ethanol.
In the laboratory, mitochondrial and nuclear DNA was extracted, amplified, purified, and sequenced following standard procedures. Genomic DNA was extracted using a DNeasy Blood and Tissue Kit (Qiagen) following the manufacturer's protocol. An $\sim 830 \mathrm{bp}$ fragment of the mtDNA was amplified for each of the 154 turtles. The mtDNA fragment encompassed the D-loop of the control region and the adjacent $\mathrm{tRNA}_{\text {Thr }}$ and tRNA $_{\text {Pro }}$ and was amplified with primers LCM15382 and H950 developed by AbreuGrobois et al. (2006). Following sample purification, this marker was sequenced using both Sanger and high-throughput sequencing (HTS) techniques as previously described (Soares et al. 2018). To determine which autosomal markers were necessary to identify hybrids, 4 nuclear segments (RAG1, RAG2, R35, CMOS) were additionally amplified and Sanger-sequenced for 79 nesting females, which had been morphologically assigned as 48 loggerheads and 31 olive ridleys (Soares et al. 2018), revealing that RAG2 was a reliable diagnostic locus for hybridization. RAG2 amplicons were then sequenced in 82 morphologically assigned loggerheads on an Illumina MiSeq. Samples were individually barcoded following the protocol of Soares et al. (2018). To ground-truth this methodology, a subset of these 82 turtles was also Sanger-sequenced for RAG2 (Soares et al. 2018). All sequences are available in GenBank under previously published accession numbers (Vilaça et al. 2012).

Each adult female was classified as either a loggerhead, an olive ridley, or a hybrid of these species based on the combined use of mtDNA, a nuclear marker (RAG2, as described by Vilaça et al. 2012), and morphology. Individual haplotypes were aligned against known sequences for the focal species using the software Geneious R8 (Kearse et al. 2012) with default alignment algorithm parameters. For mtDNA assignments, loggerhead sequences were aligned, edited, and compared to previously described haplotypes published on the Archie Carr Center for Sea Turtle Research website (https://accstr.ufl. edu/files/cclongmtdna.pdf), and olive ridley haplotypes were classified as previously described (Bowen et al. 1997). Nuclear sequences were aligned against known data for the focal species. Heterozygotes 
were assigned when the chromatograms for the nuclear markers showed the presence of both species' alleles at all diagnostic polymorphic nucleotides within the locus for each gene, as per Vilaça et al. (2012). To process the HTS reads and call single nucleotide polymorphisms (SNPs), custom Perl scripts were used that searched each turtle's processed Illumina reads, identified SNPs present for species determination, and made homozygosity or heterozygosity/hybridization calls as previously described (Soares et al. 2018). To determine a false positive detection rate, individuals of known species (e.g. pure loggerhead or olive ridley turtles) determination were identified based on the cumulative evidence of morphology, additional nuclear markers, and mitochondrial markers.

\subsection{Female morphometrics and clutch parameters}

During the field work described above, curved carapace length (CCL) was measured from the anterior point of the midline (nuchal scute) to the posterior tip of the supracaudals, and curved carapace width (CCW) was taken at the widest point (Bolten 1999). Individual females $(n=154)$ were tagged with 1 Inconel flipper tag (National Band and Tag, style 681) on each front flipper to avoid re-sampling. If a turtle was re-encountered and had more than one measurement recorded, the first record (for the first time a female was found) was used because females essentially stop growing after they become sexually mature (Bjorndal et al. 2013).

TAMAR personnel excavated every nest deposited by these 154 females after hatchlings had emerged or sufficient time had passed to ensure the nest had failed. They collected data on clutch size (CS: number of eggs in a clutch), emergence success (ES: the proportion of eggs that produced live hatchlings reaching the beach surface), hatchling production (HP: the product of CS and ES), and incubation period (IP: days between oviposition and first hatchling emergence) using previously described methods (Marcovaldi \& dei Marcovaldi 1999). With regards to these measurements, some $(\sim 21 \%)$ nests had been moved to prevent loss from erosion, inundation, or poaching. Data from both in situ (left at their original site) and transferred nests were used to calculate CS. However, because moving clutches can affect emergence success, only in situ nests were used to estimate ES, HP, and IP.
A general linear model (GLM) (ANOVA) test was then used to compare the following parameters among groups (loggerheads, olive ridleys, and their hybrids): CCL, CS, ES, HP, and IP. KolmogorovSmirnov and Levene tests were used to evaluate assumptions of normality and homogeneity of variances, and the data met these assumptions. Because olive ridleys tend to have lower CCL/CCW ratios than the other 2 groups, 3 analyses were employed to determine if individuals could be assigned to groups based on morphology. A GLM (ANOVA) test (formula $=$ GLM [CCL CCW + group]) was used to compare the relationship of CCL and CCW among groups. The CCL/CCW ratio among groups was also tested with a GLM (ANOVA), and assumptions of normality and homogeneity of variances were met, as indicated by Shapiro-Wilk and Levene tests. A linear discriminant analysis (LDA) based on CCL and CCW was run. A generalized additive model (GAM) was employed, as described by Soares et al. (2017), to statistically evaluate whether differences in body size accounted for differences among groups for CS or HP, with cubic smoothing splines and a robust quasi-likelihood error function. In GAM analyses, each covariate is conditioned on all other covariates. The significance of the contribution of each covariate to the overall model fit was evaluated with $t$-ratio statistical inference. The software program R 3.4.2 (R Core Team 2017) was used for the GLM (ANOVA) analyses, and the GAM procedures were run using S-Plus software (TIBCO Spotfire $\mathrm{S}+8.2 .0$ ). All analyses had a significance level $(\alpha)$ of 0.05 .

\subsection{Satellite telemetry}

Satellite tags were deployed in Sergipe on 8 females initially identified in the field as possible hybrids based on morphological characteristics (mixed loggerhead and olive ridley traits), and nesting behavior (typical olive ridley covering and camouflaging display called the 'ridley dance,' in which a nesting female rocks from side to side using her body to pack sand atop her nest; Safina \& Wallace 2010) (Fig. 2). Before satellite tags were attached, TAMAR researchers took measurements, conducted flipper tagging, and collected skin samples from each turtle as described in Section 2.3. The hybrid status of each of these females was later confirmed through genetic assignment as described in Section 2.2. Similarly, all turtles satellite-tracked by da Silva et al. (2011) were genetically confirmed to be olive ridleys. Out of the 10 turtles tracked by Marcovaldi et al. (2010), 2 were 


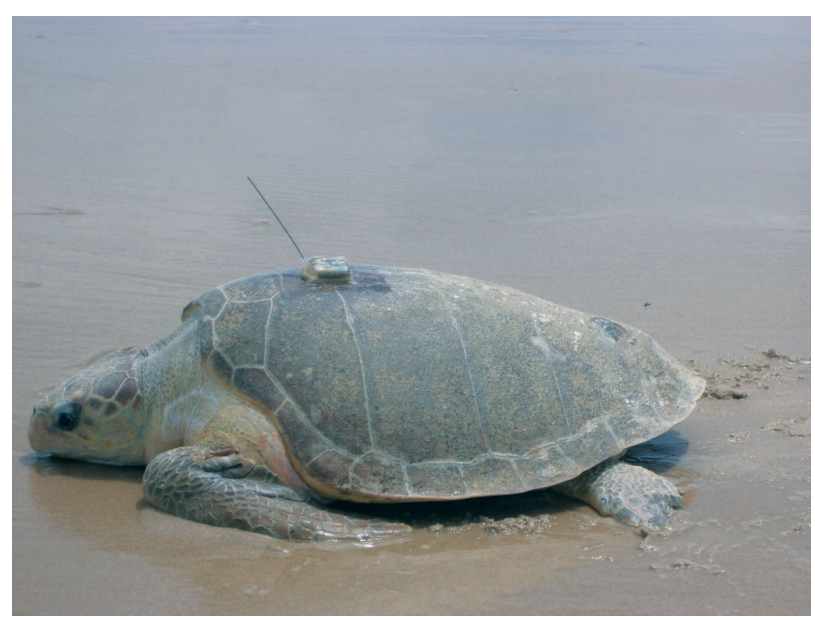

Fig. 2. Carretta caretta $\times$ Lepidochelys olivacea hybrid turtle. This individual is shown as turtle ' $\mathrm{A}$ ' in Fig. 1. This hybrid had a curved carapace length of $89 \mathrm{~cm}$ and a curved carapace width of $88 \mathrm{~cm}$ and displayed the 'ridley dance' nesting behavior characteristic of $L$. olivacea. Photo credit: TAMAR Image Bank

genetically identified as loggerheads, while for the remaining samples no genetic identification was made due to low DNA quality. Despite this lack of genetic confirmation, the extensive morphological expertise in sea turtle species identification of TAMAR's field personnel ensures species assignment reliability. The facts that loggerhead $\times$ olive ridley hybrids can be morphologically distinguished by their body size (CCL) (Soares et al. 2017, this study), and loggerhead $\times$ hawksbill hybrids were found amongst morphologically identified hawksbills (LaraRuiz et al. 2006, Vilaça et al. 2012), and in only 1.22\% of morphologically assigned loggerheads (Soares et al. 2018), provide further affirmation.

Four nesting loggerhead $\times$ olive ridley hybrids received Spot 5 (Wildlife Computers) Argos satellite transmitters between 30 January and 13 February 2012, and an additional 4 hybrids were satellitetagged between 19 January and 2 February 2013. Transmitters were attached using a 2-part epoxy resin (Tubolit MEP-301), and the units were covered with a layer of antifouling paint. The tags were powered by $2 \mathrm{D}$-size lithium batteries ( $0.5 \mathrm{~W}$ output) and duty-cycled to work continuously during the first $30 \mathrm{~d}$, with $24 \mathrm{~h}$ on/48 h off thereafter. Transmissions were processed via the ARGOS location system (https://argos-system.clsamerica.com/) for location information, battery voltage, and number and duration of transmissions.

The Satellite Tracking and Analysis Tool (STAT; Coyne \& Godley 2005) was used to analyze the location data provided by ARGOS. The methodology described by Marcovaldi et al. (2012) was followed for analysis and mapping. Routes were reconstructed using LC 1-3 positions and filtered Argos positions (LCs $0, A$, and B) based on the maximum rate of travel of $5 \mathrm{~km} \mathrm{~h}^{-1}$ and highly acute turning angles $\left(<25^{\circ}\right)$. To reduce effects of spatial autocorrelation of consecutive positions in short time intervals, a single daily location was selected. Geographic information systems software (ArcGIS 9.1, ESRI) was used to map turtle movements and calculate high-use areas and movement pathways. A post-nesting migration was considered to be completed when movement was no longer directed for at least 3 consecutive days. Movement was classified as directed if the trajectory between 2 locations was less than $45^{\circ}$ off to either side from the extension of the trajectory between the previous 2 geolocations (Zbinden et al. 2008). In foraging areas, turtles exhibit restricted movements (multidirectional and backtracked over previous tracks) following post-nesting migrations (Troëng et al. 2005). Individual core foraging areas were calculated using kernel home-range estimates (KHREs) of 50, 75, and $90 \%$ utilization distributions with Hawth's Analysis Tools for ArcGIS (Beyer 2004).

GLM (ANOVA) tests were used to compare 3 behavioral movement parameters: KHREs, residency time (number of days monitored/satellite-tracked in a given foraging area), and distance traveled (total distance traveled after leaving the nesting beach until transmission ceased). One spatial parameter (distance from the coast) was also compared in the foraging areas of loggerheads, olive ridleys, and hybrids. We employed $t$-tests to compare 2 other ecological parameters, namely water depth at foraging areas and distance from the coast, between hybrids and olive ridleys (these parameters were not available for loggerheads). All tests had an $\alpha=0.05$. Shapiro-Wilk and Levene tests were used to evaluate assumptions of normality and homogeneity of variances, which were met by the data.

\subsection{Stable isotopes}

Skin samples were collected from 69 turtles, of which 30 were loggerheads, 28 were olive ridleys, and 11 were their hybrids. Of these 69 turtles, 20 were tracked by satellite telemetry as follows: loggerheads $(\mathrm{n}=7$, Marcovaldi et al. 2010, tags applied in 2006), olive ridleys ( $\mathrm{n}=5$, da Silva et al. 2011, tags applied in 2006), and hybrids ( $\mathrm{n}=8$, this study, tags applied in 2012/2013). Skin samples were washed with deionized water and alcohol swabs to remove 
epibionts and extraneous particles. The outermost layer of the turtle epidermis was separated from the underlying tissue, finely diced with a scalpel blade, and dried at $60^{\circ} \mathrm{C}$ for $24 \mathrm{~h}$ following standard procedures (Pajuelo et al. 2012).

For analysis of $\delta^{13} \mathrm{C}$ and $\delta^{15} \mathrm{~N}$, 500 to $600 \mu \mathrm{g}$ of each tissue sample was weighed and sealed in a tin capsule and then combusted in a COSTECH ECS 4010 elemental analyzer interfaced via a FinniganMAT ConFlow III device to a Finnigan-MAT DeltaPlus XL isotope ratio mass spectrometer in the Stable Isotope Geochemistry Lab at the University of Florida. The ratios of heavy and light isotopes of an element in the sample with respect to an international standard are reported in the conventional $\delta$ notation: $\delta X=\left[\left(R_{\text {sample }} / R_{\text {standard }}\right)-1\right] \times 1000$, where $\delta X$ is the relative abundance of ${ }^{13} \mathrm{C}$ or ${ }^{15} \mathrm{~N}$ in the sample expressed in parts per thousand $(\%) ; R_{\text {sample }}$ and $R_{\text {standard }}$ are the ratios of heavy to light isotope $\left({ }^{13} \mathrm{C} /{ }^{12} \mathrm{C}\right.$ and $\left.{ }^{15} \mathrm{~N} /{ }^{14} \mathrm{~N}\right)$ in the sample and international standard, respectively. Standards used for ${ }^{13} \mathrm{C}$ and ${ }^{15} \mathrm{~N}$ were Vienna Pee Dee Belemnite and atmospheric $\mathrm{N}_{2}$, respectively. The working standard Lglutamic acid USGS40 $\left(\delta^{13} \mathrm{C}=-26.40 \%\right.$ and $\delta^{15} \mathrm{~N}=$ $-4.58 \%$ ) was calibrated monthly against international standards, and standards were inserted in all runs at regular intervals to calibrate the system. Values of $\delta^{13} \mathrm{C}$ and $\delta^{15} \mathrm{~N}$ in the skin were compared among groups with a GLM (ANOVA). The software R (R Core Team 2017) was used for all analyses, with $\alpha=0.05$. Standard ellipses, used as a measure of the isotopic niche, were calculated through the package SIBER in $\mathrm{R}$, and the standard ellipse areas were compared among groups using the Bayesian approach within the program to assess their posterior distributions (Jackson et al. 2011).

\section{RESULTS}

\subsection{Genetics}

Of the 154 skin samples from initially morphologically identified loggerheads $(\mathrm{n}=113)$ and olive ridleys ( $\mathrm{n}=41)$, 91 were ultimately classified as loggerhead turtles, 38 as olive ridley turtles, and 25 as their (loggerhead $\times$ olive ridley) hybrids, based on mitochondrial and nuclear DNA in combination with morphology. The genetic data revealed that of the 113 turtles that were morphologically similar to loggerheads, 91 had only loggerhead haplotypes and were thus identified as loggerheads. The remaining 22 turtles had both loggerhead and olive ridley haplotypes and were thus classified as hybrids. Of the 41 turtles that were morphologically similar to olive ridleys, 38 displayed only olive ridley haplotypes and were identified as olive ridleys, while 3 also had loggerhead haplotypes and were thus considered to be hybrids. Of the total 25 hybrid individuals, 1 had mtDNA that could not be amplified, 23 had olive ridley mtDNA haplotypes, and 1 had a loggerhead mtDNA haplotype.

\subsection{Female morphometrics and clutch parameters}

The nesting records for the 154 taxonomically identified females were used to identify 405 of their nests for analysis. Within each group, sample size varied among parameters because not every parameter was available for each record. As shown in Table 1, hybrids and parental species varied significantly in body size (CCL), CS, ES, and HP. Hybrids were intermediate for $\mathrm{CCL}$, and loggerheads were the largest (Table 1). There was a significant difference (ANOVA, $\mathrm{p}<0.01$ ) in the relationship between CCL and CCW among the groups (Fig. 3). Body size (CCL) had a positive relationship with body width (CCW), and although the slopes were not significantly different among groups, the intercept for hybrids was significantly higher than those for loggerheads and olive ridleys. The ratio of CCL to CCWwas also significantly different among groups $(\mathrm{p}<$ 0.01; Table S1 in the Supplement at www.intres.com/articles/suppl/n044p237_supp.pdf). Loggerheads had the highest ratio, hybrids were intermediate for this trait, and olive ridleys were 'rounder' (closer to a CCL/CCW ratio of 1). The LDA results showed the correct assignment of 88/91 $(96.70 \%)$ of loggerheads, $20 / 23(86.95 \%)$ of hybrids, and $38 / 40$ $(95.00 \%)$ of olive ridleys based on morphological data $(\mathrm{CCL}+\mathrm{CCW})$ alone.

Prior to correction for body size, all groups had significantly different CS (loggerheads > hybrids > olive ridleys; Table 1). Hybrids had similar ES to loggerheads, but both had lower ES than olive ridleys (Table 1). For HP, olive ridleys were similar to both hybrids and loggerheads, and loggerheads had significantly more hatchlings than hybrids (Table 1). The IP was similar among all groups (Table 1). However, once body size was introduced in the GAM analysis, hybrids and olive ridleys had similar CS, but larger CS than loggerheads (hybrids $\times$ loggerheads, $\mathrm{p}<$ 0.01; olive ridleys $\times$ loggerheads, $\mathrm{p}<0.05$ ) (Fig. 4). When HP was corrected for body size, there were no significant differences among the 3 groups (Fig. 4). 
Table 1. Summary statistics for morphological and reproductive parameters and stable isotope values of loggerhead and olive ridley sea turtles. CCL: curved carapace length; CS: clutch size; ES: emergence success; HP: hatchling production; IP: incubation period. Within rows, mean values with different superscripts are significantly different; p-values in bold font are significant at $\mathrm{p}<0.05$, based on GLM (ANOVA)

\begin{tabular}{|c|c|c|c|c|c|}
\hline \multicolumn{2}{|c|}{$\begin{array}{l}\text { Morphological and } \\
\text { reproductive parameters }\end{array}$} & \multirow{2}{*}{$\begin{array}{l}\text { Loggerheads } \\
\begin{array}{c}91 \\
99.9^{\mathrm{a}}(4.6) \\
90 \text { to } 114\end{array}\end{array}$} & \multirow{2}{*}{$\begin{array}{c}\text { Hybrids } \\
25 \\
88.5^{\mathrm{b}}(5.8) \\
70 \text { to } 93.5\end{array}$} & \multirow{2}{*}{$\begin{array}{l}\text { Olive ridleys } \\
38 \\
70.6^{\mathrm{c}}(3.4) \\
65 \text { to } 79\end{array}$} & \multirow{2}{*}{$\begin{array}{c}\mathrm{p} \\
<\mathbf{0 . 0 0 1}\end{array}$} \\
\hline CCL (cm) & $\begin{array}{l}\text { No. of females } \\
\text { Mean (SD) } \\
\text { Range }\end{array}$ & & & & \\
\hline CS (no. of eggs) & $\begin{array}{l}\text { No. of clutches } \\
\text { Mean (SD) } \\
\text { Range }\end{array}$ & $\begin{array}{c}336 \\
121.7^{\mathrm{a}}(27.0) \\
14 \text { to } 237\end{array}$ & $\begin{array}{c}38 \\
111.8^{\mathrm{b}}(34.4) \\
12 \text { to } 153\end{array}$ & $\begin{array}{c}31 \\
94.5^{\mathrm{c}}(23.1) \\
52 \text { to } 140\end{array}$ & $<0.001$ \\
\hline ES (\%) & $\begin{array}{l}\text { No. of clutches } \\
\text { Mean (SD) } \\
\text { Range }\end{array}$ & $\begin{array}{c}265 \\
65.0^{\mathrm{a}}(20.2) \\
5.3 \text { to } 98.8\end{array}$ & $\begin{array}{c}21 \\
60.2^{\mathrm{a}}(24.0) \\
16.0 \text { to } 96.5\end{array}$ & $\begin{array}{c}16 \\
78.9^{\mathrm{b}}(26.5) \\
15.9 \text { to } 100\end{array}$ & 0.018 \\
\hline $\begin{array}{l}\text { HP } \\
\text { (ind. clutch }{ }^{-1} \text { ) }\end{array}$ & $\begin{array}{l}\text { No. of clutches } \\
\text { Mean (SD) } \\
\text { Range }\end{array}$ & $\begin{array}{c}265 \\
78.6^{\mathrm{a}}(29.4) \\
06 \text { to } 152\end{array}$ & $\begin{array}{c}21 \\
61.3^{\mathrm{b}}(33.2) \\
06 \text { to } 114\end{array}$ & $\begin{array}{c}16 \\
69.3^{\mathrm{ab}}(28.4) \\
10 \text { to } 102\end{array}$ & 0.021 \\
\hline IP (d) & $\begin{array}{l}\text { No. of clutches } \\
\text { Mean (SD) } \\
\text { Range }\end{array}$ & $\begin{array}{c}250 \\
50.8^{\mathrm{a}}(3.2) \\
46 \text { to } 65\end{array}$ & $\begin{array}{c}12 \\
51.3^{\mathrm{a}}(2.3) \\
48 \text { to } 55\end{array}$ & $\begin{array}{c}5 \\
49.6^{\mathrm{a}}(5.2) \\
48 \text { to } 52\end{array}$ & 0.620 \\
\hline $\begin{array}{l}\text { Stable isotopes } \\
\delta^{13} \mathrm{C}\end{array}$ & $\begin{array}{l}\text { No. of samples } \\
\text { Mean (SD) } \\
\text { Range }\end{array}$ & $\begin{array}{c}30 \\
-14.9^{\mathrm{a}}(2.0) \\
-20.6 \text { to }-11.8\end{array}$ & $\begin{array}{c}11 \\
-14.4^{\mathrm{a}}(1.1) \\
-17.0 \text { to }-13.1\end{array}$ & $\begin{array}{c}28 \\
-15.2^{\mathrm{a}}(1.1) \\
-16.7 \text { to }-13.0\end{array}$ & 0.327 \\
\hline$\delta^{15} \mathrm{~N}$ & $\begin{array}{l}\text { No. of samples } \\
\text { Mean (SD) } \\
\text { Range }\end{array}$ & $\begin{array}{c}30 \\
10.1^{\mathrm{a}}(1.2) \\
7.6 \text { to } 13.5\end{array}$ & $\begin{array}{c}11 \\
10.2^{\mathrm{a}}(0.9) \\
8.7 \text { to } 11.3\end{array}$ & $\begin{array}{c}28 \\
10.6^{\mathrm{a}}(0.9) \\
08.5 \text { to } 12.5\end{array}$ & 0.227 \\
\hline
\end{tabular}

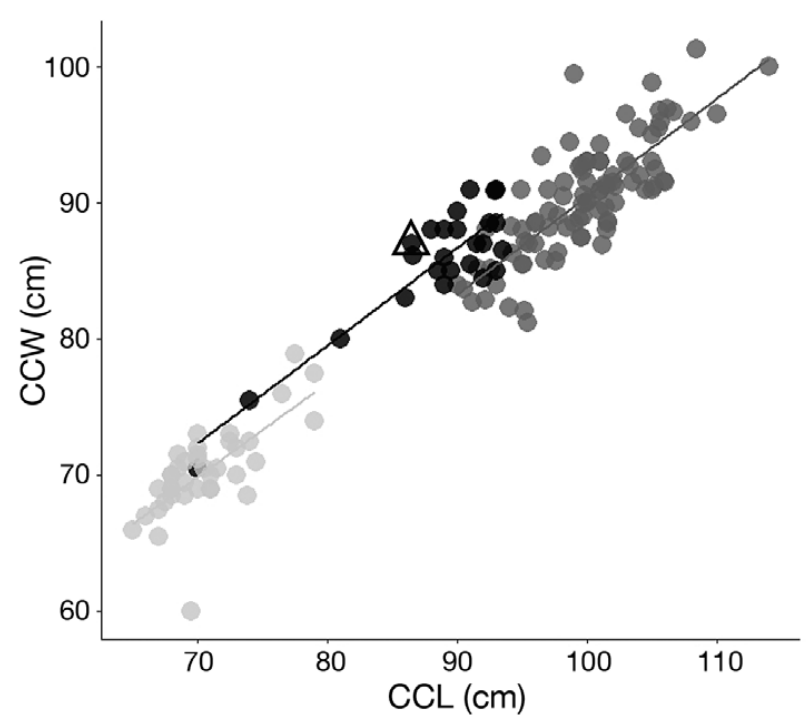

Fig. 3. Comparison of relationships between curved carapace length (CCL) and curved carapace width (CCW) among taxonomically identified loggerhead (dark gray), hybrid (black), and olive ridley (light gray) turtles. The individual with a triangle represents the only hybrid with loggerhead mtDNA. Lines represent regression slopes. Slopes are not significantly different, but the intercept of hybrids is statistically greater than those of olive ridleys and loggerheads (GLM [ANOVA], p < 0.01)

\subsection{Satellite telemetry}

Satellite telemetry revealed that the tracked hybrids shared foraging grounds with loggerhead and olive ridley turtles along the northeastern coast of Brazil, and foraged in areas adjacent to olive ridley feeding grounds in the southeast (Fig. 1). Hybrids migrated on average $19.4 \mathrm{~d}$ before reaching the foraging areas, taking less time than both loggerheads and olive ridleys (mean for each $=39.2 \mathrm{~d}, \mathrm{p}<0.05$; Table 2). For hybrids, foraging grounds were on average $771 \mathrm{~km}$ away from the nesting areas. This was not significantly different from the analogous distance for olive ridleys (mean $=1172.2 \mathrm{~km}, \mathrm{p}=$ 0.20 ), but was shorter than that for loggerheads $($ mean $=1695.8 \mathrm{~km}, \mathrm{p}<0.05)$. Foraging areas of different taxa overlapped only in the northeast: off the coast of Ceará (for 2 loggerheads and 1 hybrid); and off Pernambuco (for 1 olive ridley and 1 hybrid). In these cases, the distance between centroids ranged from 12 to $62 \mathrm{~km}$ as follows: off Ceará: $17 \mathrm{~km}$ for loggerhead 1 and hybrid $\mathrm{D}$, and $62 \mathrm{~km}$ for loggerhead 2 and hybrid $\mathrm{D}_{\text {; }}$ off Pernambuco: $12 \mathrm{~km}$ for the olive ridley and hybrid $\mathrm{B}$. 
In the foraging grounds, hybrid residency was on average $125.8 \mathrm{~d}$ before transmissions ceased, which was not significantly different from the residency of olive ridleys (mean $=73.3 \mathrm{~d}$, $p=0.65$ ). There was a significant difference in residency time of loggerheads as they were monitored on average for $479.4 \mathrm{~d}(\mathrm{p}<0.01)$. The $50 \%$ kernel home-range estimates (core foraging area) of hybrids averaged $210.4 \mathrm{~km}^{2}$, which was similar to that of olive ridleys (mean = $173.8 \mathrm{~km}^{2}, \mathrm{p}=0.81$ ), but smaller than that of loggerheads (mean = $962.1 \mathrm{~km}^{2}, \mathrm{p}<0.01$ ) (Table 2, Fig. 1). Hybrids migrated an average of $39.6 \mathrm{~km}$ from the coast, similar to
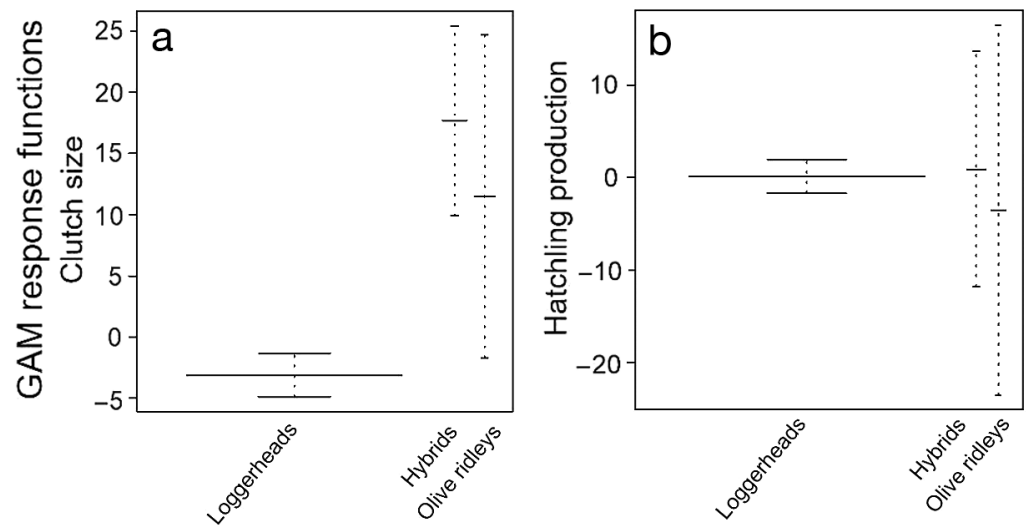

Fig. 4. Graphical summary of the generalized additive model (GAM) analyses of (a) clutch size and (b) hatchling production of groups (loggerhead, hybrid, and olive ridley turtles) with curved carapace length (CCL) as a covariate. Response functions are shown on the $y$-axis as a centered function scale. Error bars represent the $95 \%$ confidence limits olive ridleys at $25.4 \mathrm{~km}$ (Table $2 ; t$ test, $t_{9.42}=1.37, \mathrm{p}=0.20$ ). The average depth of water occupied by hybrids was $98.1 \mathrm{~m}$, which was not significantly different from that occupied by olive ridleys at $29.8 \mathrm{~m}$ (Table $2 ; t$-test, $t_{7.28}=1.59$, $\mathrm{p}=0.15)$.

\subsection{Stable isotopes}

The $\delta^{13} \mathrm{C}$ values ranged from -20.6 to $-11.8 \%$ (mean $\pm \mathrm{SD}=-14.9 \pm 2.0 \%, \mathrm{n}=30$ ) for loggerheads, -17.0 to $-13.1 \%$ o $(-14.4 \pm 1.1 \%$, $\mathrm{n}=11)$ for hybrids,

Table 2. Post-nesting and foraging data summary for loggerhead $\times$ olive ridley hybrids (this study), olive ridleys (da Silva et al. 2011), and loggerheads (Marcovaldi et al. 2010). Brazilian state abbreviations are as follows: BA: Bahia; ES: Espírito Santo; PE: Pernambuco; PB: Paraíba; CE: Ceará; PI: Piauí; RN: Rio Grande do Norte. N: total sample size; NA: not available. Data for olive ridleys and loggerheads are presented as mean, $\mathrm{SD}$, and range of values. Only the range values for distance from the coast were available for loggerheads, and there were no data on their depth. Within columns, mean values with different superscripts are significantly different at $p<0.05$. Note that residency time, i.e. the number of days spent monitored/satellitetracked in a given foraging area, may be biased by the length of time transmitters remain attached to the turtles or by how long they are actively transmitting, and should be interpreted with caution

\begin{tabular}{|c|c|c|c|c|c|c|c|c|}
\hline Groups & $\begin{array}{l}\text { Turtle } \\
\text { ID }\end{array}$ & $\begin{array}{c}\text { Foraging } \\
\text { location }\end{array}$ & $\begin{array}{l}\text { Post- } \\
\text { nesting } \\
\text { migration } \\
\text { (d) }\end{array}$ & $\begin{array}{c}\text { Distance } \\
\text { from nesting } \\
\text { grounds } \\
(\mathrm{km})\end{array}$ & $\begin{array}{l}\text { Residency } \\
\text { (d) }\end{array}$ & $\begin{array}{c}50 \% \text { kernel } \\
\text { density } \\
\text { estimates } \\
\left(\mathrm{km}^{2}\right)\end{array}$ & $\begin{array}{c}\text { Distance }(\mathrm{km}) \\
\text { from coast, } \\
\text { mean } \pm \mathrm{SD} \\
\text { (range) }\end{array}$ & $\begin{array}{c}\text { Depth }(\mathrm{m}) \\
\text { mean } \pm \mathrm{SD} \\
(\text { range })\end{array}$ \\
\hline \multirow[t]{10}{*}{ Hybrids } & $\mathrm{A}$ & $\mathrm{BA} / \mathrm{ES}$ & 15 & 850 & 215 & 261.7 & $81 \pm 6(54-100)$ & $49 \pm 2(35-52)$ \\
\hline & B & $\mathrm{PE} / \mathrm{PB}$ & 8 & 340 & 89 & 112.7 & $18 \pm 8(5-47)$ & $13 \pm 4(3-28)$ \\
\hline & $\mathrm{C}$ & $\mathrm{PE} / \mathrm{PB}$ & 13 & 358 & 284 & 394.1 & $35 \pm 6(3-69)$ & $361 \pm 194(4-1236)$ \\
\hline & $\mathrm{D}$ & CE & 15 & 950 & 17 & 253 & $31 \pm 4(20-44)$ & $17 \pm 4(10-36)$ \\
\hline & $\mathrm{E}$ & $\mathrm{ES}$ & 39 & 1191 & 136 & 179.8 & $44 \pm 5(19-75)$ & $48 \pm 40(16-360)$ \\
\hline & $\mathrm{F}$ & $\mathrm{PE}$ & 11 & 318 & 93 & 102.2 & $12 \pm 4(2-23)$ & $19 \pm 5(7-33)$ \\
\hline & G & $\mathrm{CE} / \mathrm{PI}$ & 29 & 1515 & 158 & 145.1 & $79 \pm 7(45-100)$ & $94 \pm 85(26-880)$ \\
\hline & $\mathrm{H}$ & RN & 25 & 646 & 14 & 234.5 & $17 \pm 5(8-31)$ & $184 \pm 132(11-676)$ \\
\hline & Mean & & $19.4^{\mathrm{a}}$ & $771^{\mathrm{a}}$ & $125.8^{\mathrm{a}}$ & $210.4^{\mathrm{a}}$ & $39.6^{\mathrm{a}}$ & $98.1^{\mathrm{a}}$ \\
\hline & $\mathrm{SD}$ & & 10.6 & 438.4 & 93.3 & 96.5 & 25.4 & 120.4 \\
\hline \multirow[t]{4}{*}{ Olive ridleys } & $\mathrm{N}$ & & 11 & 6 & 6 & 6 & 6 & 6 \\
\hline & Mean & & $39.2^{\mathrm{b}}$ & $1172.2^{\mathrm{a}}$ & $73.3^{\mathrm{a}}$ & $173.8^{\mathrm{a}}$ & $25.4^{\mathrm{a}}$ & $29.8^{a}$ \\
\hline & SD & & 28.3 & 916.7 & 43.7 & 91.9 & 10.2 & 14.7 \\
\hline & Range & & $14-89$ & $222-2300$ & $27-135$ & $35.2-273.6$ & $4-72$ & $9-259$ \\
\hline \multirow[t]{4}{*}{ Loggerheads } & $\mathrm{N}$ & & 13 & 10 & 15 & 15 & NA & NA \\
\hline & Mean & & $39.2^{\mathrm{b}}$ & $1695.8^{\mathrm{b}}$ & $479.4^{\mathrm{b}}$ & $962.1^{\mathrm{b}}$ & NA & NA \\
\hline & SD & & 9.8 & 362.4 & 280.0 & 373.1 & NA & NA \\
\hline & Range & & $28-47$ & $1309-2439$ & $66-932$ & $426-1777$ & $11-144.3$ & NA \\
\hline
\end{tabular}




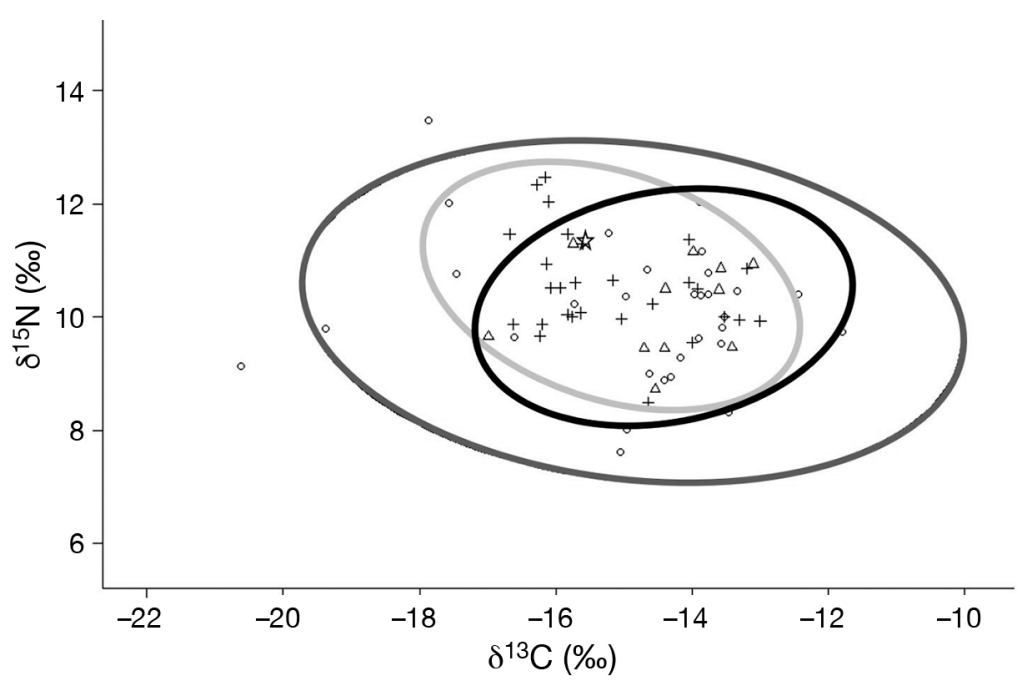

Fig. 5. Standard ellipses and isotope values for loggerhead (dark gray), hybrid (black), and olive ridley (light gray) turtles. Circles are values for individual loggerheads, triangles are hybrids, and crosses are olive ridleys. The star references the oceanic olive ridley that was satellite-tracked

populations are recovering, with increasing trends in numbers of nests (da Silva et al. 2007, Marcovaldi \& Chaloupka 2007). Here, morphological CCL and CCW measurements identified the study groups with high accuracy, suggesting the promise of this method, although further genetic ground-truthing is advised. The study hybrids had similar reproductive output, foraged in the same areas, and occupied similar ecological niches as one or both parental taxa. There was no evidence of fitness declines or loss of rarer groups to genetic swamping or other processes. Further research and long-term monitoring are recommended to determine the potential for hybrid vigor and changes of hybrid frequency within the population as well as the potential risk of the parental species being outcompeted and of hybrid populations becoming a conand -16.7 to $-13.0 \%(-15.2 \pm 1.1 \%$, $\mathrm{n}=28)$ for olive ridleys. The $\delta^{15} \mathrm{~N}$ values ranged from 7.6 to $13.5 \%$ $(10.1 \pm 1.2 \%$ o $\mathrm{n}=30$ ) for loggerheads, 8.7 to $11.3 \%$ $(10.2 \pm 0.9 \%$ o, $\mathrm{n}=11)$ for hybrids, and 8.5 to $12.5 \%$ $(10.6 \pm 0.9 \%, \mathrm{n}=28)$ for olive ridleys. The stable isotope values were not significantly different for either $\delta^{13} \mathrm{C}$ or $\delta^{15} \mathrm{~N}$ among groups (Table 1 ). There was a broad overlap of standard ellipses, or isotopic niches, for each group (Fig. 5). However, the standard ellipse area for loggerheads was significantly larger than that of the other 2 groups (Fig. 6). servation concern with respect to parental populations in the future.

\subsection{Taxonomic assignment}

Although the CCL to CCW ratio was significantly different among loggerheads, olive ridleys, and their hybrids, there was still overlap in the size ranges of individual turtles belonging to different groups. Based on the LDA, loggerheads (>96\%),

\section{DISCUSSION}

This study considers the implications of hybridization for conservation, ecology, and evolutionary biology. Hybridization between threatened loggerhead and olive ridley turtles is an ongoing process in Bahia and Sergipe, the largest colonies of both species in the South Atlantic (Marcovaldi \& dei Marcovaldi 1999). As noted in Section 1, hybridization between these species in Brazil is estimated at $27 \%$ (Reis et al. 2010). Although the number of olive ridley females is significantly greater than that of loggerhead females in Sergipe, and the reverse is true in Bahia (De Castilhos et al. 2011, Santos et al. 2011), both

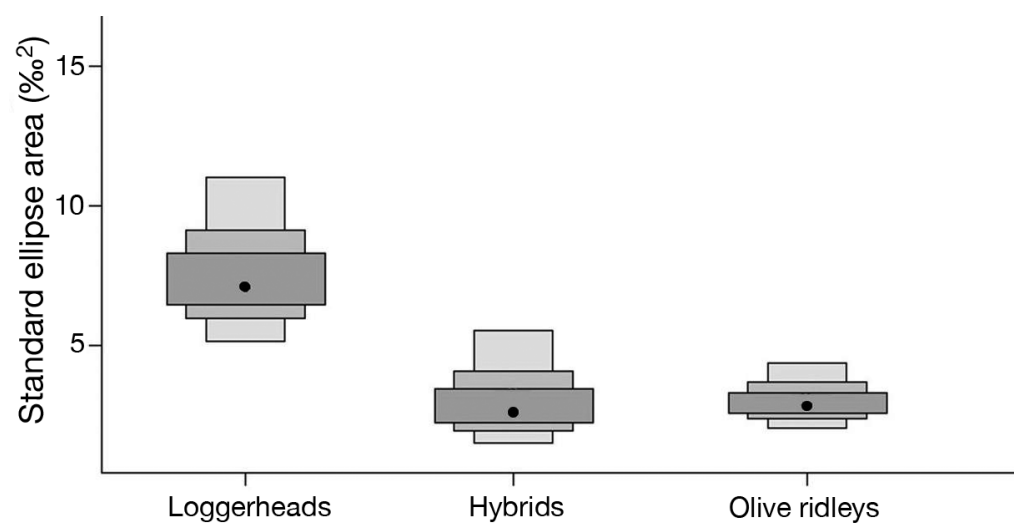

Fig. 6. Standard ellipse areas (SEAs) for loggerhead, hybrid, and olive ridley turtles. Black dots represent the mode, and shaded boxes represent 50 , 75 , and 95 credibility intervals from dark to light grey. Loggerheads have a significantly larger ellipse, or isotopic niche, area than the other taxa. The probability that loggerhead SEA is less than hybrid SEA is 0.008, and the probability that loggerhead SEA is less than olive ridley SEA is 0.000 . However, the niche areas of olive ridleys and hybrids are comparable; hybrid SEA and olive ridley SEAs are not significantly different 
olive ridleys $(95 \%)$, and their hybrids (>86\%) could be discriminated. These results suggest high confidence in assigning the different groups based on CCL and CCW, especially for loggerheads and olive ridleys. For animals falling in a possible hybrid category based on the LDA results, genetic confirmation is recommended.

We also observed that the majority of our samples $(23 / 25)$ had olive ridley mtDNA, indicating that most hybrids are a result of mating between a female olive ridley and a male loggerhead. Similar to loggerhead $\times$ hawksbill hybrids (Vilaça et al. 2012), the nesting seasons of these 2 species overlap in Sergipe, with the reproductive peak of loggerheads occurring before that of olive ridleys (da Silva et al. 2007, Marcovaldi \& Chaloupka 2007, De Castilhos et al. 2011, Santos et al. 2011). Therefore, there is temporal overlap of male loggerheads and female olive ridleys, which could explain the mating bias. A similar mating bias due to temporal overlap was observed in hawksbill $\times$ loggerhead hybrids in Bahia (Vilaça et al. 2012).

\subsection{Reproductive output}

Our study shows for the first time that, when body size is accounted for, loggerhead $\times$ olive ridley hybrid females produce similar numbers of hatchlings per clutch as parental species, and therefore do not seem to be at a reproductive disadvantage. Soares et al. (2017) similarly found no evidence of a reproductive disadvantage in loggerhead and hawksbill hybrids. These findings suggest that hybrids could persist in the region despite documented increases in the nest numbers of both parental species, and that interspecific mating need not represent a sink for the reproductive effort of parental species.

Furthermore, both parental species show increasing population recovery trends (da Silva et al. 2007, Marcovaldi \& Chaloupka 2007). Hybrids might contribute to current parental species' population estimates due to misidentification. However, the increasing presence of pure individuals may also reduce hybrid numbers in the future, since population decreases, combined with overlapping nesting seasons, are contributing factors to the high frequency of hybridization in Brazil (Vilaça et al. 2012). Indeed, further studies are needed to understand the longterm effects on hybrids beyond the first filial generation $\left(F_{1}\right)$. It remains unclear, for example, whether hybridization is a recent event, or if generations be- yond the $F_{1}$ were not detected due to factors such as lower fitness in different life stages.

Hybrid loggerhead $\times$ olive ridley turtles showed an intermediate body size compared to their parental species (Table 1). CS was also intermediate for these hybrids (Table 1). However, when body size was accounted for, CS of hybrids and olive ridleys was similar, and both were larger than that of loggerheads (Fig. 4). Thus, on the basis of female body size, hybrids and olive ridleys laid similar numbers of eggs per clutch. In contrast, loggerhead $\times$ hawksbill hybrids were larger than either loggerheads or hawksbills (Soares et al. 2017). CS was also similar between loggerhead $\times$ hawksbill hybrids and hawksbills, which both produced larger clutches than loggerheads when CCL was not a covariate. However, when CCL was accounted for, CS of loggerhead $\times$ hawksbill hybrids was significantly lower than that of hawksbills, but not smaller than that of loggerheads (which also had significantly lower CS than hawksbills). In both types of hybrids, after correction for body size, CS was similar to the parental species with the larger $\mathrm{CS}$, consistent with no reduction in hybrid fitness for this measure.

Loggerhead $\times$ olive ridley hybrids and loggerhead turtles had similar ES; both were lower than that of olive ridleys (Table 1). In comparison, loggerhead $x$ hawksbill hybrids had lower ES than either parental species (Soares et al. 2017). With respect to HP, loggerhead $\times$ olive ridley hybrids were similar to olive ridley turtles, but lower than loggerheads, while loggerhead $\times$ hawksbill hybrids had lower HP than both parental species. However, when body size was accounted for, both loggerhead $\times$ olive ridley and loggerhead $\times$ hawksbill hybrids produced similar numbers of hatchlings as the parental species (Fig. 4), which is inconsistent with reduced hybrid fitness for these traits. Our data were collected over a wide temporal scale, and did not allow for analysis of other important reproductive parameters such as clutch frequency within a nesting season and breeding frequency, which integrate the contribution of hatchings entering a population over time (see Soares et al. 2017). Nonetheless, this study reveals that female loggerhead $\times$ olive ridley hybrids are fertile and, when adjusted for body size, hybrids produce similar numbers of hatchlings per clutch (HP) as the parental species. Loggerheads and hawksbills are phylogenetically more distant than loggerheads and olive ridleys (Naro-Maciel et al. 2008). Therefore, loggerhead $\times$ hawksbill hybrids could be expected to be more prone to genetic incompatibilities than loggerhead $\times$ olive hybrids. However, based on the results 
of this study and that of Soares et al. (2017), this predicted pattern of genetic incompatibilities based on phylogenetic distance is not reflected in their reproductive success as measured by HP.

Vilaça et al. (2012) showed that most loggerhead $x$ olive ridley hybrids analyzed were of the first filial generation $\left(F_{1}\right)$, suggesting that some reproductive barrier could be affecting progeny fertility. However, based on the fertility of hybrid loggerhead $\times$ olive ridleys reported here, this does not now seem as likely. Also, the viability of hybrid loggerhead $\times$ olive ridley progeny (Soares et al. 2018) suggests that at least for the embryonic life stage, these hybrids have similar survival as pure species. However, the survival of loggerhead $\times$ olive ridley hybrids at other life stages could be different and needs to be evaluated. Failure to observe advanced intercross progeny could theoretically be attributed to generation time. If hybridization between loggerheads and olive ridleys is more recent than between loggerheads and hawksbills, we would not expect to see advanced intercross progeny because hybrids would just now be reaching reproductive maturity. Still another possibility, and perhaps the most likely, is that with more powerful genomic tools and more genetic analyses, more incidences of multigenerational cross progeny will be uncovered (Driller et al. preprint https://doi. org/10.1101/2020.04.03.024331).

\subsection{Migration and movements}

The hybrids in this work made similar migrations as, and foraged in shared areas with, loggerheads and olive ridleys studied by Marcovaldi et al. (2010) and da Silva et al. (2011), respectively. Because these studies are several years apart, it is worth noting that although the actual overlap among foraging areas was not observed in the same time periods, we believe that these spatial preferences are real. These ecological and behavioral aspects of hybrid biology suggest that their roles in marine ecosystems are comparable to those of their parental species. However, the extent of direct competition between hybrids and their parental species is not yet clear. Differential selection of microhabitats or prey items within similar trophic levels may lessen competition, or hybrids may eventually outcompete one or both parental species. In contrast, satellite-tracked postnesting loggerhead $\times$ hawksbill hybrids used loggerhead foraging areas along the coast of Brazil rather than hawksbill feeding grounds (Marcovaldi et al. 2012).
Telemetry studies of morphologically assigned postnesting loggerheads from Bahia and olive ridleys from Sergipe revealed the foraging areas and migratory patterns of each species (Marcovaldi et al. 2010, da Silva et al. 2011, Santos et al. 2019). Tag returns and stranding data from morphologically assigned adult loggerheads in Brazil have shown connectivity with areas in the southernmost part of the country (Monteiro et al. 2016). In contrast, stranding data indicate that morphologically assigned adult and juvenile olive ridleys apparently occur only in very low numbers in southernmost Brazil and adjacent Uruguayan waters (Monteiro et al. 2016, GonzálezParedes et al. 2017), although Santos et al. (2019) showed that olive ridleys migrated to the southern Brazilian coast. Post-nesting loggerhead $\times$ olive ridley turtles showed similar migration patterns to those of loggerheads and most olive ridleys, remaining in neritic habitats throughout their migrations until reaching foraging grounds. Some olive ridleys displayed this behavior, but others made oceanic migrations (da Silva et al. 2011, Santos et al. 2019), even crossing the Atlantic to feed along the African west coast (Santos et al. 2019). Loggerhead turtles had longer migration durations than hybrids when migrating to a common foraging area, because loggerheads traveled longer distances from their nesting beaches in the southern state of Bahia to the feeding ground. Olive ridleys and hybrids leaving the state of Sergipe to a common foraging site had similar migration distances and durations.

Core feeding grounds (50\% KHREs) were similar for hybrids and olive ridleys, and smaller than those of loggerheads. Residency times varied among groups, with loggerheads, in some cases, satellitetracked for over $2 \mathrm{yr}$ in the same foraging areas. There were no significant differences in the residency periods for hybrids and olive ridleys. However, residency times may be greatly biased by the length of time transmitters remain attached to the turtles, or by how long they are actively transmitting, and should be interpreted with caution. Distance from the coast and water depth were also not significantly different between hybrids and olive ridleys that remained neritic, but summarized loggerhead data were not available for comparison (Marcovaldi et al. 2012; Table 2). Although all of the satellite data reported to date show loggerheads migrating only to the northern part of Brazil (Marcovaldi et al. 2012), there is an important foraging area for morphologically identified large juvenile and adult loggerheads along the southernmost coast of Brazil (Monteiro et al. 2016, Santos et al. 2019). Both loggerheads and 
olive ridleys are exposed to the threat of incidental capture in several fisheries (e.g. fish corrals, shrimp trawlers, longline fisheries) throughout their migratory routes and foraging grounds (Sales et al. 2008, da Silva et al. 2011, Marcovaldi et al. 2012, Santos et al. 2019), and hybrids are almost certainly subjected to these threats as well.

\subsection{Stable isotopes and ecological niches}

The niche concept is central to ecological thinking and is used to evaluate a variety of parameters including resource use, geographic diversity, and many aspects of community composition and structure (McGill et al. 2006). The ecological niche is represented as an n-dimensional hypervolume, partitioned into scenopoetic axes (characterized primarily by where the focal organisms live) and bionomic axes (characterized primarily by consumption patterns) (Hutchinson 1957, 1978). It has been argued that location on these axes may be quantified using stable isotopic ratios (Bearhop et al. 2004), and the concept of the isotopic niche as an equivalent to the ecological niche has been formalized (Newsome et al. 2007).

Values of $\delta^{13} \mathrm{C}$ and $\delta^{15} \mathrm{~N}$ from hybrids and parental species were similar, and the ellipse areas, which are used to define isotopic niches and thus ecological niches, overlap (Table 1, Fig. 5). Even though the isotopic signatures were comparable among groups, loggerheads had a significantly larger ellipse, or isotopic niche (Fig. 6). Previous research showed that loggerheads and olive ridleys have similar diets in Brazil, consisting mainly of crustaceans (Colman et al. 2014, Di Beneditto et al. 2015), although they differ in some prey items and foraging behavior (Bjorndal 1997). The greater size of the loggerhead trophic niche may reflect the substantial numbers of these turtles using foraging areas in the southernmost part of Brazil. This great geographic distance could be sufficient to encompass a greater diversity of prey items, leading to a broader range of $\delta^{13} \mathrm{C}$ values.

In the North Atlantic, carbon and nitrogen isotopes have been successfully used to assign foraging areas to nesting loggerheads (Ceriani et al. 2012, Pajuelo et al. 2012) and explore the plasticity of their resource use (Vander Zanden et al. 2010), although possible differences between years and foraging strategies (Hawkes et al. 2006) also need to be considered. Unlike in the North Atlantic, here it was not possible to define either a latitudinal gradient, or specific foraging areas, based on stable isotope values with respect to satellite telemetry patterns. In Brazil, 2 studies evaluated the stable isotopic compositions of $\delta^{13} \mathrm{C}$ and $\delta^{15} \mathrm{~N}$ in morphologically assigned loggerheads (Medeiros et al. 2015, 2019) and olive ridleys (Petitet \& Bugoni 2017). The former study used bone collagen as the tissue source, but unfortunately, no correlation between this and other tissues is possible at this time. The latter study analyzed multiple tissues and showed the plasticity of olive ridley diets and foraging habitats, with lipid-extracted values from skin samples of $\delta^{13} \mathrm{C}(\mathrm{n}=43$, mean $\pm \mathrm{SD}=-16.56$ $\pm 0.74 \%$, range $=-17.90$ to $-14.86 \%$ ) , and $\delta^{15} \mathrm{~N}(\mathrm{n}=$ 43 , mean $=10.83 \pm 1.27 \%$, range $=6.41$ to $13.67 \%$ o). These values are similar to those we report for olive ridley turtles identified here (Table 1).

\subsection{Conservation applications and future research directions}

Understanding movement patterns between nesting and foraging grounds is essential for the conservation of endangered sea turtles and other organisms, and key for developing management strategies. In sea turtles particularly, knowledge of movement patterns is important so that the impacts of fisheries, dredging, and other anthropogenic disturbances can be evaluated accordingly. Conservation strategies designed to protect the parental species by mitigating threats will also protect hybrids. The results of our study show that hybrids are apparently exposed to similar threats on nesting beaches as parental species, as they share areas of coastal development alongside loggerheads and olive ridleys in Bahia and Sergipe. On their migrations and at their foraging grounds, hybrids are also exposed to fisheries that potentially interact with both loggerheads and olive ridleys.

Many knowledge gaps must be filled to fully comprehend the biology of hybrid sea turtles. The potential for hybrid vigor, the potential risk of the parental species being outcompeted by hybrids, and the consequent hybrid populations becoming a conservation concern with respect to parental populations in the future is beyond the scope of this study, and demands further attention and monitoring. More research is needed to elucidate the remarkable phenomenon observed among the 3 hybridizing species of sea turtles in Brazil, its consequences to each species, changes in frequency of hybrids in the coming years, and how the hybrids and parental species interact with their habitats. Genome-wide surveys should be conducted with a focus on nuclear genes under strong selective pressure, to evaluate potential incompatible alleles. Recent studies have shown that 
introgression is negligible in Brazilian sea turtle populations (Arantes et al. 2020, Brito et al. 2020), and that nesting females are first-generation hybrids $\left(F_{1}\right)$. The absence of $>\mathrm{F}_{2}$ female adults in samples from the past $15-20$ yr shows that Brazilian sea turtle populations are not being significantly impacted genetically by hybridization, and that genetic integrity of each species may be kept given the high presence of pure individuals relative to hybrids. Nonetheless, analyses to evaluate the fitness costs for hybrids are needed at different life stages for several demographic parameters such as age at maturity, growth rates, and longterm survivorship. Based on what we have learned so far, any sea turtle population within the Cheloniidae family may be capable of hybridizing given the appropriate temporal and geographical overlap (Bowen \& Karl 2007). We recommend that populations for which this scenario is possible be genetically screened with appropriate genome-wide markers. In conclusion, this study on the abundance, reproductive output, fitness, and ecology of loggerhead $\times$ olive ridley hybrid sea turtles suggests that these hybrids may persist along with other sea turtle nesting populations in the region, with research and conservation applications.

Acknowledgements. All of the study procedures involving animals were in accordance with the ethical standards of the University of Florida and Projeto TAMAR/Fundação PróTAMAR, where the studies were conducted. This research was approved by the Institutional Animal Care and Use Committees at the University of Florida (201101985) and conducted under SISBIO permit 28938-3 from the Brazilian Ministry of the Environment. Samples were exported under CITES permit 13BR010456/DF and were imported into the USA under CITES permits 13US724540/9 (Archie Carr Center for Sea Turtle Research). We are very grateful to Projeto TAMAR/Fundação Pró-TAMAR personnel for their help collecting data, especially L. Veríssimo, B. Canal, P. Luz, R. Machado, and D. Mora. We thank A. Santos and G. Maurutto for assisting with extracting data from the Projeto TAMAR database and for their help with Fig. 1. We thank L. Medeiros for reviewing this manuscript. We are also grateful to R. Lo and M. Schlig for the indispensable assistance processing the genetic samples, and to S. McDaniel and A. Payton for providing equipment and expertise on genetic analyses. We also thank J. Curtis and the Stable Isotope Lab at the University of Florida for assistance with stable isotope analysis. We are grateful to H. B. Vander Zanden and M. Pajuelo for guidance with stable isotope analyses and sample preparation. We thank J. P. Gomez for assisting with GLM (ANOVA) analysis. S.T.V. is currently supported by the European Union's Horizon 2020 Research and Innovation Programme under the Marie Sklodowska-Curie grant agreement 844756 (TurtleHyb). This work received awards from the following funding sources: PADI Foundation, Archie Carr Center for Sea Turtle Research general funds, Tropical Conservation and Development Grant, Maturo
Excellence Fund, Lerner-Gray Memorial Fund, College of Staten Island of the City University of New York, Beckman Foundation, Michael L. May Research Grants, and a generous donation from Lalita Shastry.

\section{LITERATURE CITED}

Abreu-Grobois FA, Horrocks J, Formia A, LeRoux R and others (2006) New mtDNA Dloop primers which work for a variety of marine turtle species may increase the resolution capacity of mixed stock analysis. In: Frick M, Panagopoulou A, Rees AF, Williams K (eds) Book of abstracts of the 26th Annual Symp Sea Turtle Biol Conserv, Crete, Greece, 3-8 April 2006, p 179

Abreu-Grobois A, Plotkin P (2008) Lepidochelys olivacea The IUCN Red List of Threatened Species. 2008: e.T11534A3292503. http://dx.doi.org/10.2305/IUCN.UK. 2008.RLTS.T11534A3292503.en (accessed 1 September 2020)

Arantes LS, Vilaça ST, Mazzoni CJ, Santos FR (2020) New genetic insights about hybridization and population structure of hawksbill and loggerhead turtles from Brazil. J Hered 111:444-456

Arnold ML, Hodges SA (1995) Are natural hybrids fit or unfit relative to their parents? Trends Ecol Evol 10:67-71

* Bearhop S, Adams CE, Waldron S, Fuller RA, Macleod H (2004) Determining trophic niche width: a novel approach using stable isotope analysis. J Anim Ecol 73: 1007-1012

* Beyer HL (2004) Hawth's analysis tools for ArcGIS. www. spatialecology.com/htools (accessed 01 August 2020)

Bjorndal KA (1997) The foraging ecology and nutrition of sea turtles. In: Lutz PL, Musick J (eds) The biology of sea turtles, Vol 1. CRC Press, Boca Raton, FL, p 199-231

* Bjorndal KA, Parsons J, Mustin W, Bolten AB (2013) Threshold to maturity in a long-lived reptile: interactions of age, size, and growth. Mar Biol 160:607-616

Bolten AB (1999) Techniques for measuring turtles. In: Eckert K, Bjorndal K, Abreu-Grobois F, Donnelly M (eds) Research and management techniques for the conservation of sea turtles. IUCN/SSC Marine Turtle Specialist Group Publication No. 4. MTSG, Washington, DC, p 110-114

Bowen BW, Karl SA (2007) Population genetics and phylogeography of sea turtles. Mol Ecol 16:4886-4907

Bowen BW, Clark AM, Abreu-Grobois FA, Chaves A, Reichart HA, Ferl RJ (1997) Global phylogeography of the ridley sea turtles (Lepidochelys spp.) as inferred from mitochondrial DNA sequences. Genetica 101:179-189

* Brito C, Vilaça ST, Lacerda AL, Maggioni R, Marcovaldi MÂ, Vélez-Rubio G, Proietti MC (2020) Combined use of mitochondrial and nuclear genetic markers further reveal immature marine turtle hybrids along the South Western Atlantic. Genet Mol Biol 43:e20190098

Casale P, Tucker A (2017) Caretta caretta (amended version of 2015 assessment). The IUCN Red List of Threatened Species. 2017: e.T3897A119333622. http://dx.doi.org/10. 2305/IUCN.UK.2017-2.RLTS.T3897A119333622.en (accessed 1 September 2020)

Ceriani SA, Roth JD, Evans DR, Weishampel JF, Ehrhart LM (2012) Inferring foraging areas of nesting loggerhead turtles using satellite telemetry and stable isotopes. PLOS ONE 7:e45335

* Colman LP, Sampaio CLS, Weber MI, de Castilhos JC (2014) Diet of olive ridley sea turtles, Lepidochelys olivacea, in the waters of Sergipe, Brazil. Chelonian Conserv Biol 13: $266-271$ 
Coyne MS, Godley BJ (2005) Satellite Tracking and Analysis Tool (STAT): an integrated system for archiving, analyzing and mapping animal tracking data. Mar Ecol Prog Ser 301:1-7

da Silva A, de Castilhos JC, Lopez GG, Barata PCR (2007) Nesting biology and conservation of the olive ridley sea turtle (Lepidochelys olivacea) in Brazil, 1991/1992 to 2002/2003. J Mar Biol Assoc UK 87:1047-1056

da Silva ACCD, dos Santos EAP, Oliveira FLdC, Weber MI, Batista JAF, Serafini TZ, de Castilhos JC (2011) Satellitetracking reveals multiple foraging strategies and threats for olive ridley turtles in Brazil. Mar Ecol Prog Ser 443: 237-247

De Castilhos JC, Coelho CA, Argolo JF, Allan E (2011) Avaliação do estado de conservação da tartaruga marinha Lepidochelys olivacea (Eschscholtz, 1829) no Brasil. Biodivers Bras 1:28-36

Di Beneditto APM, Fulgencio De Moura J, Siciliano S (2015) Feeding habits of the sea turtles Caretta caretta and Lepidochelys olivacea in south-eastern Brazil. Mar Biodivers Rec 8:e122

*González-Paredes D, Vélez-Rubio G, Hahn AT, Caraccio MN, Estrades A (2017) New records of Lepidochelys olivacea (Eschscholtz, 1829) (Testudines, Cheloniidae) provide evidence that Uruguayan waters are the southernmost limit of distribution for the species in the Atlantic Ocean. Check List 13:863-869

Hawkes LA, Broderick AC, Coyne MS, Godfrey MH and others (2006) Phenotypically linked dichotomy in sea turtle foraging requires multiple conservation approaches. Curr Biol 16:990-995

Hutchinson GE (1957) Concluding remarks. Cold Spring Harb Symp Quant Biol 22:415-427

Hutchinson G (1978) An introduction to population biology. Yale University Press, New Haven, CT

Jackson AL, Inger R, Parnell AC, Bearhop S (2011) Comparing isotopic niche widths among and within communities: SIBER - Stable Isotope Bayesian Ellipses in R. J Anim Ecol 80:595-602

Kearse M, Moir R, Wilson A, Stones-Havas S and others (2012) Geneious Basic: an integrated and extendable desktop software platform for the organization and analysis of sequence data. Bioinformatics 28:1647-1649

Lara-Ruiz P, Lopez GG, Santos FR, Soares LS (2006) Extensive hybridization in hawksbill turtles (Eretmochelys imbricata) nesting in Brazil revealed by mtDNA analyses. Conserv Genet 7:773-781

Mallet J (2005) Hybridization as an invasion of the genome. Trends Ecol Evol 20:229-237

* Marcovaldi MÂ, Chaloupka M (2007) Conservation status of the loggerhead sea turtle in Brazil: an encouraging outlook. Endang Species Res 3:133-143

Marcovaldi MÂ, dei Marcovaldi GG (1999) Marine turtles of Brazil: the history and structure of Projeto TAMARIBAMA. Biol Conserv 91:35-41

* Marcovaldi MÂ, Lopez GG, Soares LS, Lima EHSM, Thomé JCA, Almeida AP (2010) Satellite-tracking of female loggerhead turtles highlights fidelity behavior in northeastern Brazil. Endang Species Res 12:263-272

Marcovaldi MÂ, Lopez GG, Soares LS, López-Mendilaharsu M (2012) Satellite tracking of hawksbill turtles Eretmochelys imbricata nesting in northern Bahia, Brazil: turtle movements and foraging destinations. Endang Species Res 17:123-132

McGill BJ, Enquist BJ, Weiher E, Westoby M (2006) Rebuilding community ecology from functional traits. Trends Ecol Evol 21:178-185
Medeiros L, da Silveira Monteiro D, Petitet R, Bugoni L (2015) Effects of lipid extraction on the isotopic values of sea turtle bone collagen. Aquat Biol 23:191-199

* Medeiros L, Monteiro DS, Botta S, Proietti MC, Secchi ER (2019) Origin and foraging ecology of male loggerhead sea turtles from southern Brazil revealed by genetic and stable isotope analysis. Mar Biol 166:76

Monteiro DS, Estima SC, Gandra TBR, Silva AP and others (2016) Long-term spatial and temporal patterns of sea turtle strandings in southern Brazil. Mar Biol 163:247

Naro-Maciel E, Le M, FitzSimmons NN, Amato G (2008) Evolutionary relationships of marine turtles: a molecular phylogeny based on nuclear and mitochondrial genes. Mol Phylogenet Evol 49:659-662

* Newsome SD, Martinez del Rio C, Bearhop S, Phillips DL (2007) A niche for isotopic ecology. Front Ecol Environ 5: 429-436

Pajuelo M, Bjorndal KA, Reich KJ, Vander Zanden HB, Hawkes LA, Bolten AB (2012) Assignment of nesting loggerhead turtles to their foraging areas in the Northwest Atlantic using stable isotopes. Ecosphere 3:89

* Petitet R, Bugoni L (2017) High habitat use plasticity by female olive ridley sea turtles (Lepidochelys olivacea) revealed by stable isotope analysis in multiple tissues. Mar Biol 164:134

Pritchard PCH, Mortimer JA (1999) Taxonomy, external morphology, and species identification In: Eckert K, Bjorndal K, Abreu-Grobois F, Donnelly M (eds) Research and management techniques for the conservation of sea turtles. IUCN/SSC Marine Turtle Specialist Group Publication No. 4. MTSG, Washington, DC, p 21-38

* Proietti MC, Reisser J, Marins LF, Marcovaldi MA and others (2014) Hawksbill $\times$ loggerhead sea turtle hybrids at Bahia, Brazil: Where do their offspring go? PeerJ 2:e255

Core Team (2017) R: a language and environment for statistical computing. R Foundation for Statistical Computing, Vienna. https://www.r-project.org

Reis EC, Soares LS, Vargas SM, Santos FR and others (2010) Genetic composition, population structure and phylogeography of the loggerhead sea turtle: colonization hypothesis for the Brazilian rookeries. Conserv Genet 11: 1467-1477

Rhymer JM, Simberloff D (1996) Extinction by hybridization and introgression. Annu Rev Ecol Syst 27:83-109

Safina C, Wallace BP (2010) Solving the 'ridley riddle.' SWOT Rep 5:26-30

Sales G, Giffoni BB, Barata PCR (2008) Incidental catch of sea turtles by the Brazilian pelagic longline fishery. J Mar Biol Assoc UK 88:853-864

Santos A, Soares L, Marcovaldi M, Monteiro D, Giffoni B, Almeida A (2011) Avaliação do estado de conservação da tartaruga marinha Caretta caretta (Linnaeus, 1758) no Brasil. Biodivers Bras 1:3-11

Santos EAP, Silva ACCD, Sforza R, Oliveira FLC and others (2019) Olive ridley inter-nesting and post-nesting movements along the Brazilian coast and Atlantic Ocean. Endang Species Res 40:149-162

* Soares LS, Bolten AB, Wayne ML, Vilaça ST, Santos FR, dei Marcovaldi MAG, Bjorndal KA (2017) Comparison of reproductive output of hybrid sea turtles and parental species. Mar Biol 164:9

* Soares LS, Bjorndal KA, Bolten AB, dei Marcovaldi MAG and others (2018) Effects of hybridization on sea turtle fitness. Conserv Genet 19:1311-1322

Stronen AV, Paquet PC (2013) Perspectives on the conservation of wild hybrids. Biol Conserv 167:390-395 
Todesco M, Pascual MA, Owens GL, Ostevik KL and others (2016) Hybridization and extinction. Evol Appl 9:892-908

Troëng S, Evans DR, Harrison E, Lagueux CJ (2005) Migration of green turtles Chelonia mydas from Tortuguero, Costa Rica. Mar Biol 148:435-447

Vander Zanden HB, Bjorndal KA, Reich KJ, Bolten AB (2010) Individual specialists in a generalist population: results from a long-term stable isotope series. Biol Lett 6:711-714

Editorial responsibility: Kartik Shanker,

Bangalore, India

Reviewed by: 2 anonymous referees
Vilaça ST, Vargas SM, Lara-Ruiz P, Molfetti É and others (2012) Nuclear markers reveal a complex introgression pattern among marine turtle species on the Brazilian coast. Mol Ecol 21:4300-4312

* Zbinden JA, Aebischer A, Margaritoulis D, Arlettaz R (2008) Important areas at sea for adult loggerhead sea turtles in the Mediterranean Sea: Satellite tracking corroborates findings from potentially biased sources. Mar Biol 153:899-906

Submitted: May 18, 2020

Accepted: November 10, 2020

Proofs received from author(s): March 1, 2021 